\title{
A Survey of BeAver LoCATION ANd Habitat To MODEL THEIR DISTRIBUTION IN Grand Teton National PARK, WyOMing
}

\author{
$\gamma$
}

WILLIAM J. GRIBB $\uparrow$ HENRY J. HARLOW

UNIVERSITY OF WYOMING-NATIONAL PARK

SERVICE RESEARCH STATION

UNIVERSITY OF WYOMING † LARAMIE

\begin{abstract}
$\downarrow \quad$ INTRODUCTION
A species that attracted a considerable amount of attention during the early years of American colonization and western exploration was the beaver (Castor canadensis). So important was this species that treaties between European countries specifically identified the trading of its furs (Long, 2000). It is estimated that over 60 million beavers were removed from the North American landscape between the early 1600s through the late 1800 s (Long, 2000). By the beginning of the 1900s it is believed that only $10 \%$ of the pre-settlement population of beavers remained. Though not extinct, their numbers were radically reduced because of the fur trade and their "destructive" behavior of cutting trees and ponding water that interfered with America's growth. This perception of their detriment to the environment has been dramatically changed, and they are now perceived as ecosystem engineers that assist in creating beneficial habitat and restoring damaged landscapes (Naiman et al., 1988). Thus, it is essential in this revised role, that we know the distribution of the beaver, their habitats, and to determine the best management practices to utilize their benefits to the ecosystem.
\end{abstract}

Problem Statement: There is inadequate information on the distribution and habitat of beavers (Castor canadensis) in Grand Teton National Park (GTNP) since 1977. This project will complete a survey of the Snake River and its side-channels for beaver colonies and record their location and adjacent habitat.

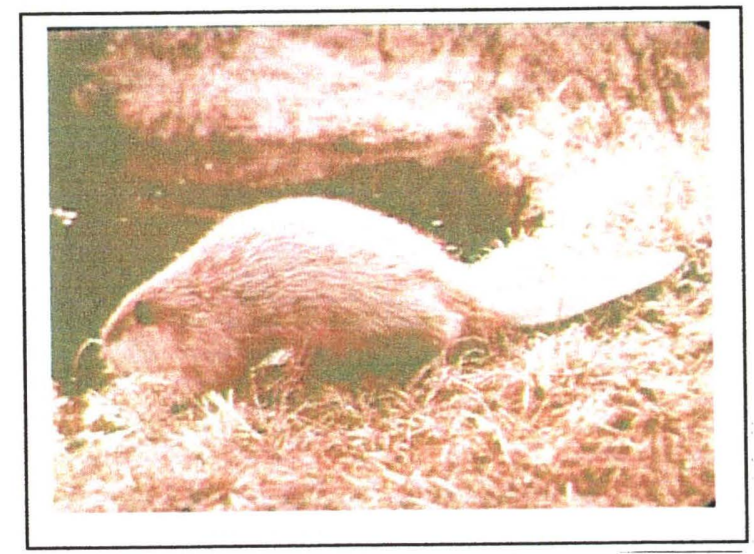

In the period 1976-1977 Collins (1976) completed his survey of Castor canadensis in GTNP and found almost 100 colonies throughout the park. Just along the Snake River he found between 37-49 colonies inhabiting the area from Jackson Lake dam to Moose, WY. This $44.2 \mathrm{~km}$ stretch of the Snake River had a density of 0.96 colonies per $\mathrm{km}$. Unfortunately, a corresponding figure for density throughout the park was not calculated. Collins surveyed along the Snake River, some of its main tributaries, and a few of the lakes and ponds in the park. Table 1. provides a summary of Collins' 
findings and the areas that he surveyed. A number of areas were not surveyed along the western sides of Jackson Lake and eastern flatlands.

\begin{tabular}{|l|l|l|}
\hline Table 1. & $\begin{array}{l}\text { Collins' } \\
\text { Average } \\
\text { Colonies } \\
1976- \\
1977\end{array}$ & $\begin{array}{l}\text { Gribb } \\
\text { Dens/Lodges } \\
\text { 2002-2004 }\end{array}$ \\
\hline $\begin{array}{l}\text { Snake River } \\
\text { (Jackson L. Dam to } \\
\text { Moose) }\end{array}$ & 42.5 & 22 \\
\hline Buffalo River & 3.5 & 3 \\
\hline Pacific Creek & 4.25 & 2 \\
\hline Arizona Creek & 5.5 & 0 \\
\hline Willow Flats & 7.5 & 0 \\
\hline Oth. Lakes/Ponds & 21.25 & 8 \\
\hline Oth. Streams & 8 & 8 \\
\hline Total & 92.5 & 43 \\
\hline
\end{tabular}

The Snake River drainage can be divided into five major beaver areas: Snake River from Yellowstone NP to Jackson Lake; drainage into Jackson Lake; Snake River south of Jackson Lake to Moose; drainage into the Snake River from the east; and drainage into the Snake River from the west. This project completed a survey of four out of the five beaver areas (Table 1.). During the summers of 2002, 2003 and 2004 over $173 \mathrm{~km}$ of streams and lakeshore were surveyed for beaver activity. Appendix A. lists all of the areas surveyed with lengths of stream or shoreline investigated.

The ground survey information recorded the location (using GPS), the type of beaver activity, and attempted to sample habitat characteristics as defined by Allen (1982). Allen constructed a model of the beaver's habitat needs and constraints so that it would be possible to predict potential locations of beavers on a river landscape and to assist in beaver reintroduction programs. The main habitat factors identified by Allen are: vegetation cover type; crown cover percent; size of trees; height of shrubs; stream gradient; and, stream fluctuation (Appendix B). In 1990 Johnson and Naiman successfully employed remote sensing techniques to identify beaver habitats and examine the role of the beaver in an overall ecosystem for beaver location prediction, this project is the first stage in such a research progression.

The various beaver habitats have been well documented over the last several decades (Retzer, et al) (Beidleman, 1959; Leege, 1968; Johnston and Naiman, 1990; Olson and Hubert, 1994; and, Strong,
1997). This project will utilize this information along with field data to construct a habitat suitability index model as defined by Allen (1982). Utilizing GIS tools and spatial analytical techniques, a computer derived model will provide the first step in determining potential beaver habitats. Additional techniques will be employed to establish the benchmarks for the model, to calibrate the variables, and to determine the level of correspondence between the model and field observations (Honachefsky, 2000).

This project had three main objectives:

1.) utilizing GPS and GIS technologies, locate and map beaver activities as well as habitat characteristics on the Snake River.

2.) examine the differences between Collins (1976) and the more recent beaver activity field data.

3.) establish habitat characteristics for active beaver locations to model potential habitat areas.

\section{DENSITIES}

As stated earlier, Collins (1976) found between 37-49 active bank dens/lodges along the Snake River, but he also identified 47 abandoned bank dens or lodges. Thus, there is almost a 1 to 1 ratio between active and abandoned dens and lodges. In the 1988-89 study by Consolo-Murphy and Hanson (1993) and Consolo-Murphy and Tatum (1995) they found slightly different percentages of active (56\%) and abandoned (44\%) dens and lodges out of 76 sites. In the three years of this study (20022004), the authors found radically different percentages across Grand Teton National Park between active and abandoned dens and lodges, 43 active (34\%) and 86 abandoned sites (66\%). However along the Snake River, the comparison between active and abandoned sites are similar to the other findings, 22 active (47\%) and 25 inactive (53\%). Except for GTNP overall, it appears that there is generally a 50-50 split between active and abandoned dens and lodges.

Densities of beavers along water courses or in lakes/ponds appear to vary. Collins in his study found an average of 42.5 colonies along the $44.2 \mathrm{~km}$ Snake River from Jackson Lake dam to Moose, producing a density of $.96 / \mathrm{km}$. The authors found only 22 active dens and lodges along this same portion of the Snake River producing a density of .5 colonies per $\mathrm{km}$. This density is similar to those calculated by Breck et al, (2001) for beaver colonies 
along the regulated Green River of approximately .5.6 colonies $/ \mathrm{km}$. However in the same study, they also calculated a density of $.35 / \mathrm{km}$ along the unregulated Yampa River. Thus, the Collins' density figure is quite high and could represent the peak carrying capacity of the river.

A combination of factors may account for the lower density of the authors' study. First, in 1997 the unusual drawdown from Jackson Lake was over twice the normal release $(12,200 \mathrm{cfs})$ in mid-summer (Figure 1). But, the release of water from Jackson Lake is irregular over the year and over the years. Figure 1 illustrates this point quite distinctly. Several authors have recognized the impacts of the changes in flood regimes to plant and animal distribution and abundance (Lytle, 2002; Kingsford, 2000; Nilsson and Dynesius, 1994; and Nilsson, et al., 1991). According to Breck et al (2001) little is known about the impacts of flow regulation on beaver populations. In fact, there are differing opinions as to whether or not the population increases or decreases with stable flows. They do state that beaver density is a function of the availability of forage, thus if flood regimes improve riparian vegetation (Hughes and Cass, 1997) then there should be an increase in beavers. However, if stable flow decreases riparian vegetation regeneration and diversity the opposite should occur. Breck et al, (2003) concluded in their study of responses to flow regulation, that beaver habitat conditions were better on the regulated Green River because of the increase availability of willows and experienced a decrease in predation because the willows were an island-oriented species.

Figure 1. Snake River flow.

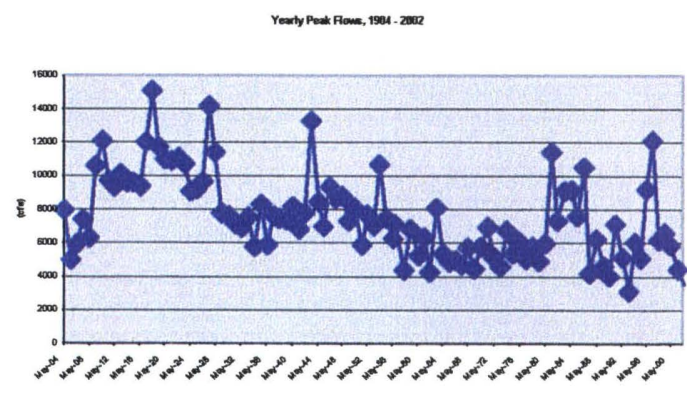

The availability of cottonwood, aspen, alder and willows is a key element of beaver location. The higher density of beaver in the 1974-1977 required a larger number of plant communities to sustain their numbers. However, over time the beaver may have impacted a large percentage of their older plant communities. Barnes and Mallick (2001) found that even after 12 years, there was not a re-establishment of the aspen plant communities around abandoned beaver dam sites. In a sample plot to investigate the impact of beaver on tree stands, in an area southwest of Schwabacher's Landing (110m x $50 \mathrm{~m}$ plot) a count of beaver-cut tree stumps and trees revealed that there were 138 tree stumps out of 321 trees found $(43 \%)$, with the stumps ranging in size from $15-60 \mathrm{~cm}$ in diameter. Thus, the impacts of beavers to their habitat is substantial and over a long period could be disastrous.

Another factor influencing the decrease in beaver population could be the low precipitation levels over the last several years. Wyoming has been in a drought condition for the last five years Micheli and Ostermann (2003). This can be illustrated by the lack of soil moisture across the area (Figure 2.). The resulting low stream flow causes back and side channels to become dry. It is these areas off the main channel of the Snake River that beaver lodges are most prominent (Collins, 1976; Olson and Hubert, 1994), an vulnerable to drought.

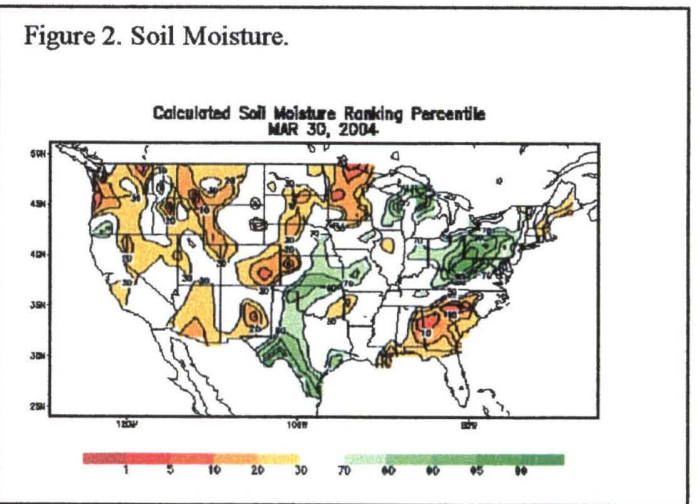

\section{$\downarrow$ METHODOLOGY}

To obtain each of the three main objectives requires the use of different techniques and tools. To continue the field survey of beaver dens and lodges, a systematic ground survey of waterways was conducted. Appendix A lists the creeks, rivers, ponds and lakes surveyed by either walking or paddling with a the watercraft (raft or canoe). If beaver activity was identified, its location was recorded using a GPS unit along with the type of activity and if it was active, i.e., current, or historic. Habitat information was gathered, initially, at active den/lodge locations. A $30 \mathrm{~m} \times 30 \mathrm{~m}$ grid was established for six sites adjacent to the den/lodge. 
Vegetation information on species, density, canopy cover, and ground cover were recorded (Allen, 1982). Thus, basic information about the location and habitat of the den/lodge were captured at known locations. Abandoned dens/lodges were also located, but the habitat information was not recorded at these sites.

\section{$\downarrow \quad$ ANALYSIS}

ArcGISv9.0 was used to map and analyze known beaver locations and habitat. The analysis of the beaver locations has two parts. First, determine if there is a spatial difference between the Collins and Gribb distribution of beavers. And second, examine the habitat characteristics of beavers to construct a model of potential beaver habitats. Figure 3. is a map of the distribution of active dens/lodges that were located along the Snake River between 2002 and 2004. The 22 active dens/lodges are clustered around the confluence with the Buffalo Forks and after Deadman's Bar through the braided portions of the Snake River near Schwabacher's Landing. Though activity was identified in the Willow Flats area, no den or lodge could be located. Figure 4. is a map of the distribution of active dens/lodges that were located by Collins over the three year period 19741977 along the Snake River. Collins found a very heavy concentration of beavers in the Willow Flats, confluence with Pacific Creek, Buffalo Forks and Spread Creek, but not as many beavers in the area of the braided Snake River south of Deadman's Bar and adjacent to Schwabacher's Landing. A weighted distance analysis of beaver concentrations reveals that in the Collins' surveys the average distance from the Jackson Lake dam is $15.96 \mathrm{~km}$, while the same average for the Gribb surveys reveals an increased distance downstream to $25.45 \mathrm{~km}$. Thus, it appears that there is a southern migration of beaver's along the Snake River below Jackson Lake dam.

To determine if there is a significant difference in the distribution of beavers in 1974-77 and 2002-04, two different statistical techniques, using a standardized spatial grid, were calculated from the collected locations. A separate quadrat analysis was performed on each of the data sets to examine if they were randomly distributed. The second technique, the variance-mean-ratio (VMR) statistical test, also compares the distribution of points to a random distribution (McGrew and Monroe, 1999), but compares the Gribb distribution to the Collins distribution. The standardized spatial grid was a $200 \mathrm{~m} \times 2 \mathrm{~km}$ series of continuous cells centerlined on the Snake River from Jackson Lake dam to Moose. Figure 5. reveals a difference in the concentration of dens/lodges between Collins and Gribb as the cells proceed downstream.

Figure 3. The distribution of active beaver dens/lodges identified between 2002 and 2004 .

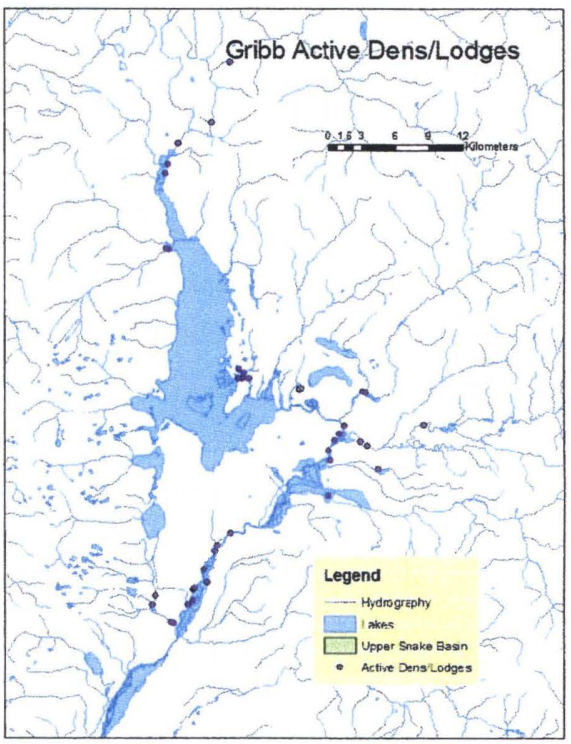

Figure 4. Distribution of active dens/lodges in the period 19741977.

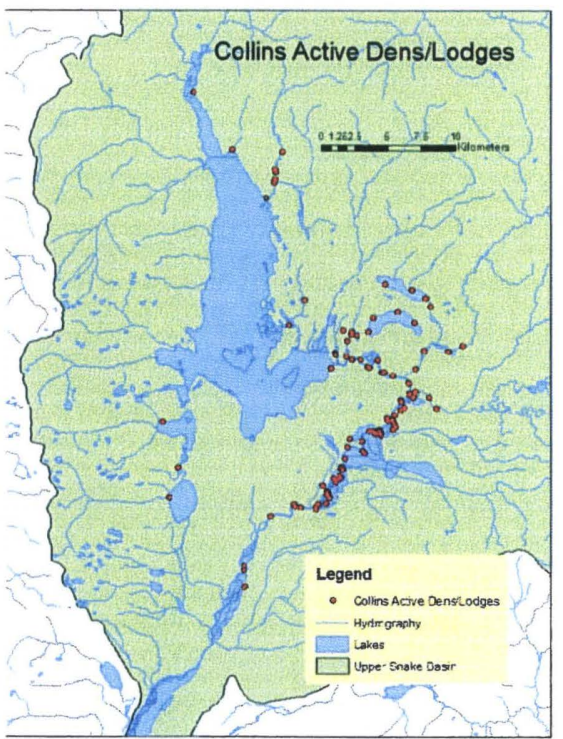




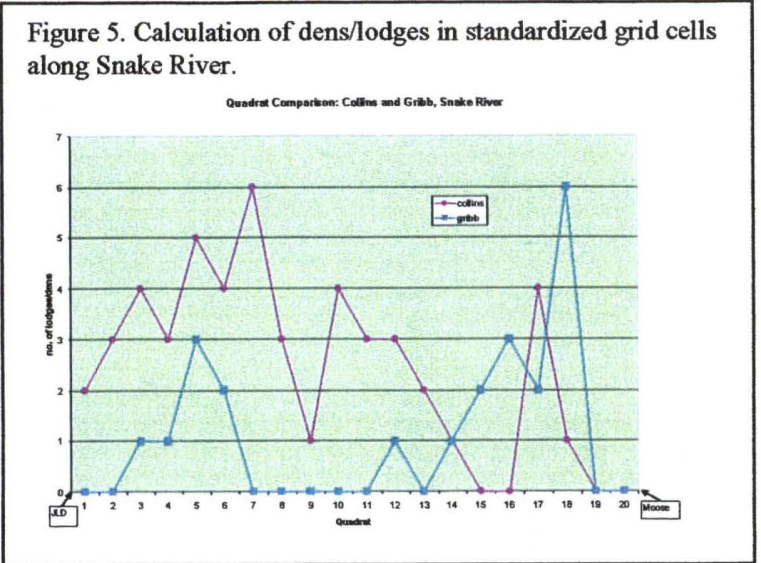

\begin{tabular}{|c|c|c|}
\hline & Number & \\
\hline $\begin{array}{l}\text { Dens/Lodges in Grid } \\
\text { Cell }\end{array}$ & Collins & Gribb \\
\hline 0 & 4 & 10 \\
\hline 1 & 3 & 4 \\
\hline 2 & 2 & 3 \\
\hline 3 & 5 & 2 \\
\hline$>3$ & 6 & 1 \\
\hline
\end{tabular}

To determine if the distribution of the number of dens/lodges in the standardized spatial grid is random, quadrat analysis was performed based on the identified locations (Table 1). The null hypothesis is that there is no difference between the frequency distribution of the number of dens/lodges in the cells and a random distribution. This hypothesis was rejected for the Collins distribution of dens/lodges, but was not rejected for the Gribb distribution, both at $\rho=.05$. A chi-square test also revealed that there is a statistical difference between the Collins' and Gribb frequency distribution of dens/lodges in grid cells at $\rho=.05$.

The VMR statistic also determined that there is no difference between the Gribb distribution of beaver locations $(\mathrm{VMR}=.98)$ and random $(\rho=.05)$. However, the same test did calculate that the Collins' distribution is more dispersed in a systematic arrangement $(\mathrm{VMR}=.69)$ at $\rho=.05$. Thus, there is a spatial difference between the two beaver distributions.

Over the three years of locating the active dens/lodges not enough information was gathered on habitat characteristics to produce a viable habitat suitability index (HSI). Because of time constraints, only six sites were surveyed for information on habitat characteristics. From the sampled sites, there was too much variability to produce any reliable statistics. The average percent tree crown cover is $23 \%$ with a standard deviation of $26 \%(\mathrm{COV}=113 \%)$. The average percent of trees with a dbh between 2.5 and $25 \mathrm{~cm}$ is $56.6 \%$ with a standard deviation of $18.1 \%(\mathrm{COV}=31.9 \%)$. The shrub cover on average is almost twice the tree crown cover at $54.9 \%$, with a standard deviation of $34.5 \%(\mathrm{COV}=62.8 \%)$. The average shrub height is $1.65 \mathrm{~m}$ with a .9 standard deviation $(\mathrm{COV}=55.9 \%)$. While the percent dominate tree cover is almost $87 \%$, with a standard deviation of $31.3 \%(\mathrm{COV}=36.0 \%)$. The dominant species community is the Aspen-Alder-CottonwoodWillow (13 of 24 sites), while a mix of deciduous species is the second most common community ( 9 of 24 sites). Table 2 provides specific base information on the main variables of percent tree cover, percent shrub cover, and average shrub height relative to their location to the bank den (the darkened cell) and their river position. Table $2 \mathrm{~b}$ lists the coefficients of variation for each of the grid sites and it is easy to determine that there is too much variability in the averages to suggest any trends. An interpretation of the site statistics reveals no spatial pattern to any of the variables. A more detailed inventory of the habitat characteristics will have to be completed before these basic factors can be analyzed in more detail.

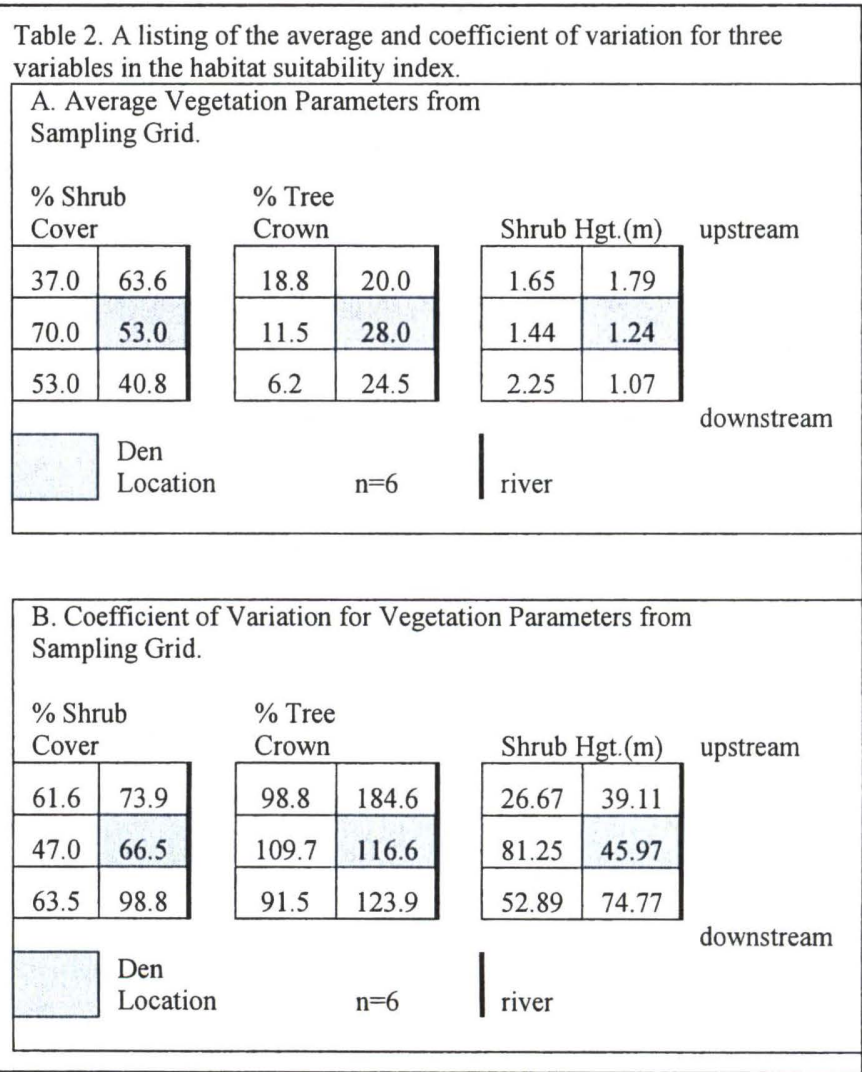


To produce a more strict habitat model, a number of other researchers have identified additional factors that could be considered. These include: stream width; floodplain width; upstream drainage area; discharge variability; size, type and distance to herbaceous woody matter; height of banks; stream order; and soil texture (Lawrence, 1954; Munther, 1981; Merritt, 1987: Barnes and Millik, 1997; Suzucki and McComb, 1998; Swimley, et. al., 1998; and, Barnes and Mallik, 2001). The integration of these different variables into the habitat model would seem appropriate, however, this would entail a new series of observations and data collection.

\section{SUMMARY}

The difference in beaver distribution between the 1977 Collins' and the 2004 Gribb surveys are quite dramatic. There has been an overall decrease in the number of active beaver dens and lodges. There has been an almost $50 \%$ decline in the active dens/lodges 92 versus 46 . This is also apparent in the density of beaver dens/lodges along the Snake River. Collins identified approximately one den/lodge per $\mathrm{km}$ of river $(.96 / \mathrm{km})$, while Gribb found only .5/km. Again an almost $50 \%$ decrease in density of beavers. There was also a spatial change in the density of beavers, with a movement southward of the beaver locations, between Collins and Gribb. The weighted average distance of beaver dens/lodges from the Jackson Lake Dam migrated downstream $10 \mathrm{~km}$ between the Collins' and Gribb surveys ( $15.96 \mathrm{~km}$ to $25.45 \mathrm{~km})$.

Unfortunately, there were not enough samples of habitat characteristics to provide statistically significant information applicable to a habitat suitability index according to Allen (1982). However, a survey of the literature reveals that a more complex model could or should be employed that expands the number of environmental characteristics of beaver habitat.

\section{$\downarrow$ REFERENCES AND BIBLIOGRAPHY}

Allen, A.W., 1982, Habitat suitability index models: beavers, U.S. Fish and Wildlife Service, FWS/OBS-82/10.30 (revised), Ft. Collins, CO.
Barnes, D.M. and A.U. Mallik, 1997, "Habitat factors influencing beaver dam establishment in northern Ontario watersheds," J. of Wildlife Management, 61(4), 1371-1377.

Barnes, D.M. and A.U. Mallik, 2001, "Effects of beaver, Castor canadensis, herbivory on streamside vegetation in a northern Ontario watershed," Canadian Field-Naturalist, 115(1), 9-21.

Beidleman, R.G., 1959, The American Beaver, Thorne Ecological Research Station, Bull. No. 7, Boulder, Colorado.

Breck, S.W., K.R. Wilson, and D.C. Andersen, 2003, "Beaver herbivory of willow under two flow regimes: a comparative study on the Green and Yampa rivers," Western North American Naturalist, 63(4), 463-471.

Breck, S.W., K.R. Wilson, and D.C. Andersen, 2001, "The demographic response of bankdwelling beavers to flow regulation: a comparison on the Green and Yampa rivers," Canadian Journal of Zoology, 79: 1957-1964.

Collins, T.C., 1976, Population Characteristics and habitat Relationships of Beavers, Castor canadensis, in northwest Wyoming. Unpublished Ph.D. thesis, University of Wyoming.

Consolo-Murphy, S. and D.D. Hanson, 1993, "Distribution of beaver in Yellowstone National Park, 1988-89," in Ecological Issues on Reintroducing Wolves into Yellowstone National Park, R.S. Cook, ed., USDI, NPS Scientific Monograph NRSM93/22, pp. 38-48.

Consolo-Murphy, S. and R.B. Tatum, 1995, "Distribution of beaver in Yellowstone National Park, 1994," unpublished manuscript.

Honachefsky, W.B., 2000, Ecologically Based Municipal Land Use Planning, Boca Raton, FL: Lewis Publishers. 
Hughes, J.W. and W.B. Cass, 1997, "Pattern and process of a floodplain forest, Vermont, USA: predicted responses of vegetation to perturbation," Journal of Applied Ecology, 34: 594-612.

Johnston, C.A., J. Pastor and R.J. Naiman, 1993, "Effects of beaver and moose on boreal forest landscapes," in Landscape Ecology and GIS, R. Haines-Young, D.R. Green, and S.H. Cousins, ed., London: Taylor and Francis, pp. 237-254.

Johnston, C.A. and R.J. Naiman, 1990, "Browse selection by beaver: effects on riparian forest composition," Canadian J. of Forest Research, 20, 1036-1043.

Kingsford, R.T., 2000, "Ecological impacts of dams, water diversions and river management on floodplain wetlands in Australia," Australian Ecology, 25: 109-127.

Lawrence, W., 1954, Michigan Beaver Populations as Influenced by Fire and Logging, Ph.d. dissertation, U. of Michigan, Ann Arbor, MI, microfilm.

Leege, T.A., 1968, "Natural movements of beavers in southeastern Idaho," J. of Wildlife Management, 32(4), 973-976.

Long, K., 2000, Beavers: A Wildlife Handbook, Boulder, CO: Johnson Books.

Lytle, D.A., 2002, "Flash floods and aquatic insect life-history evolution: evaluation of multiple models," Ecology, 83(2): 370-385.

McGrew, J.C. and C.B. Monroe, 1999, An Introduction to Statistical Problem Solving in Geography, Englewood Cliffs, NJ: Prentice-Hall, Inc.

Merritt, J.F., 1987, Guide to the Mammals of Pennsylvania, Pittsburg, PA: U. of Pittsburg Press.

Micheli, R. and T. Ostermann, 2003, Wyoming Drought Plan, Wyoming Governor's Office, Cheyenne, Wyoming.

Munther, G., 1981, "Beaver Management in grazed riparian ecosystems," in Peake, J.M. and
P.D. Dalke, eds., Wildlife-Livestock Relationships, Symposium: Proc. 10, Coeur D'Alene, ID, Moscow, ID: U. of Idaho Wildlife and Range Experiment Station, pp. 234-241.

Naiman, R.J., C.A. Johnston, and J.C. Kelly, 1988, "Alteration of north American streams by beaver," BioScience, 38(11), 753-762.

Nilsson, C. and M. Dynesius, 1994, "Ecological effects of river regulation on mammals and birds: a review; Regulated Rivers Research Management, 9: 45-53.

Nilsson,C., A. Ekbald, M. Gardfjell, and B. Carlberg, 1991, "Long term effects of river regulation on river margin vegetation," Journal of Applied Ecology, 28: 963-987.

Olson, R. and W.A. Hubert, 1994, Beaver: Water Resources and Riparian Habitat Manager, Laramie, WY: U. of Wyoming.

Pullman, H.R., J.B. Dunning, and J. Liu, 1992, "Population dynamics in complex landscapes: a case study," Ecological Applications 2(2), 165-177.

Retzer, J.L., H.M. Swope, J.D. Remington, and W.H. Rutherford, 1956, Suitability of Physical Factors for Beaver Management in the Rocky Mountains of Colorado, Colorado Department of Game and Fish, Tech. Bull. No. 2.

Strong, P., 1997, Where Waters Run Beavers, Minnetonka, MN: NorthWord Press.

Suzucki, N. and W.C. McComb, 1998, "Habitat classification models of beavers (Castor canadensis) in the streams of the central Oregon Coast Range," Northwest Science, 72(2), 102-110.

Swimley, T.J., T.L. Serfass, R.P. Brooks and W.M. Tzilkowski. 1998, "Predicting river otter lactrine sites in Pennsylvania," Wildlife Bulletin, 26(4), 836-845. 
Appendix A.

Surveyed Areas in Grand Teton and Yellowstone National Parks

Underlined sections have been surveyed, as of 29 September 2004

Snake River (SN)

Yellowstone NP Boundary to Heart Lake Trail river crossing-

$11.5 \mathrm{~km}(\mathrm{SN} 1)$

YNP Boundary to Flagg Ranch-4.7km (SN2)

Flagg Ranch to Jackson Lake-9.4km (SN3)

Jackson Lake to Deadmans-27.7km (SN4)

Deadman's to Bar BC-11.7km (SN5)

Bar BC to Moose-4.8km (SN6)

Snake River Tributaries flowing west into Snake River Sheffield Creek-. $5 \mathrm{~km}(\mathrm{SH})$

$\underline{\text { Pacific Creek-5.7km (PA) }}$

Two Ocean Lake stream into Pacific Creek-5.9km (PA1)

Buffalo Fork-11.3km (BU)

Spread Creek-6.3km (SP)

\section{Rivers flowing east into Jackson Lake and Snake River}

Polecat Creek-6.1km (PO)

Glade Creek-10.9km (GL)

Berry Creek-16.8km [eastern $1.3 \mathrm{~km}$ ] (BE)

Owl Creek-9.4km (OW)

Webb Canyon

Moose Creek-12.7km (MO)

North Fork-2.7km (NM1)

South Fork-8.9km (NM2)

North Moran Creek-3.9km (NM)

North Fork-4.1km (MOR1)

South Fork-5.5km (MOR2)

Moran Creek-8km (MOR)

Leigh Canyon Creek-12.1km (LE)

Cascade Creek-11.6km (CA) 
Cottonwood Creek-8.3km from Snake, $13.8 \mathrm{~km}(\mathrm{CO})$

\section{$\underline{\text { Taggart Creek-1.8km (TC) }}$}

Beaver Creek-1.5km (BC)

Rivers Flowing west into Jackson Lake and Snake River from GTNP Boundary

Lizard Creek-5.6km (LI)

Arizona Creek-6.5km (AR)

Third Creek-5.8km (TH)

Second Creek-3.2km (SE)

Pilgrim Creek-8.6km (PI)

Spring Creek- w.branch-2.7km (SPI1)

e.branch-1.8km (SPI2)

Christian Creek-2.2km (CH)

Lakes

Shoreline of Jackson Lake at $6770^{\prime}-75.6 \mathrm{~km}(\mathrm{JL})$

Shoreline of Swan Lake-4.2km (SW)

Shoreline of Heron Pond-1.6km (HP)

Shoreline of Two Ocean Lake-9.6km (TOL)

Shoreline of Emma Matilda Lake-3.9km of $11.9 \mathrm{~km}$ (SW1/4) (EML)

Shoreline of Christian Pond-2.1 km (CP)

Shoreline of Elk Ranch Reservoir-1.6km of 3.3km (W1/2) (ERR)

Miscellaneous

East/West of US287, 6km south of Flagg Ranch-(US287)

Other Random Sites-(OTH)

\section{LISTING-in bold, surveved areas}

AR Arizona Creek, GTNP boundary to delta with Jackson Lake

BC Beaver Creek, headwaters to confluence with Cottonwood $\mathrm{Cr}$

BE Berry Creek, headwaters to delta with Jackson Lake

BU Buffalo Creek, GTNP boundary to confluence with Snake

CA Cascade Creek, headwaters to delta with Jenny Lake

$\mathrm{CH} \quad$ Christian Creek, Christian Pond into Snake

CO Cottonwood Creek, Jenny Lake to confluence with Snake

CP Christian Pond

EML Emma Matilda Lake

ERR Elk Ranch Reservoir

GL Glade Creek, headwaters to confluence with Snake

HP Heron Pond

JL Jackson Lake

LE Leigh Canyon Creek, headwaters to delta with Jackson Lake 
LI

MO

NM

NM1

NM2

OTH

OW

PA

PI

PO

SE

SH

SPI1

SPI2

SN1

SN2

SN3

SN4

SN5

SN6

SP

SW

TC

TH

TOL

US287
Lizard Creek, GTNP boundary to delta with Jackson Lake Moose Creek, headwaters to confluence with Berry Creek North Moran Creek, headwaters to delta with Jackson Lake North fork N. Moran Creek, headwaters to confluence with N. Moran Cr. South fork N. Moran Creek, headwaters to confluence with N. Moran Cr. Other, random sites of beavers on unnamed ponds or creeks Owl Creek, headwaters to confluence with Jackson Lake Pacific Creek GTNP boundary to confluence with Snake Pilgrim Creek, GTNP boundary to delta with Jackson Lake Polecat Creek, Headwaters to confluence with Jackson Lake Second Creek, headwaters to delta with Jackson Lake Sheffield Creek, headwaters to confluence with Snake Spring Creek, west branch to confluence with Snake Spring Creek, east branch to confluence with Snake Yellowstone NP Boundary to Heart Lake Trail Crossover GTNP Boundary to Flagg Ranch Flagg Ranch to Jackson Lake Jackson Lake to Deadmans Deadmans to Bar BC Ranch Bar BC Ranch to Moose Spread Creek, GTNP Boundary to confluence with Snake Swan Pond

Taggart Creek, headwaters to confluence with Snake Third Creek, headwaters to delta with Jackson Lake Two Ocean Lake

East/West side of US287 south of Flagg Ranch 